\title{
In Vitro Rooting of Hypocotyl Cuttings of Fraser Fir
}

\section{Carole H. Saravitz', Frank A. Blazich ${ }^{2}$, and Henry V. Amerson ${ }^{3}$ Department of Horticultural Science, North Carolina State University, Raleigh, NC 27695-7609}

Additional index words. Abies fraseri, auxin, indolebutyric acid, conifers, Christmas trees

Abstract. Hypocotyl cuttings were prepared from Ii-week-old aseptically grown seedlings of Fraser fir [Abies fraseri (Pursh) Poir.] and cultured 18 days on media containing 0 to $40 \mathrm{mg}$ IBA/liter followed by transfer to the same medium without auxin. Greatest rooting $(66 \%)$ occurred after treatment with $20 \mathrm{mg}$ IBA/liter, whereas the greatest number of roots per rooted cutting (7.4) was noted following treatment with $40 \mathrm{mg} \cdot \mathrm{liter}^{-1}$. Chemical name used: 1H-indole-3-butyric acid (IBA).

Hypocotyl cuttings, seedlings with the radicle removed, have been used to study in vitro rooting of several conifers, including Scotch pine (Pinus sylvestris L.) (Grönroos and von Arnold, 1985); lodgepole pine ( $P$. contorts Dougl. ex Loud. ) (Grönroos and von Arnold, 1987); and loblolly pine (P. taeda L.) (Amerson et al., 1985). Experiments using hypocotyl cuttings may potentially increase knowledge of root initiation and development, particularly for development of procedures for in vitro- propagation involving rooting of adventitious shoots. Amerson et al. (1988) observed $\approx 15 \%$ to $20 \%$ greater rooting of hypocotyl cuttings than of adventitious shoots and were able to use data acquired using hypocotyl cuttings to improve in vitro rooting of adventitious shoots of loblolly pine.

Research has been conducted to develop procedures for tissue culture propagation of Fraser fir, the most valuable Christmas tree species grown in North Carolina.. Adventitious buds and subsequent budbreak in vitro have been reported using embryonic explants of Fraser fir (Saravitz et al., 1987; Zygmont and Schwarz, 1987). Our attempts to root these shoots have been unreliable, perhaps due, in part, to lack of knowledge regarding optimum auxin concentrations. Therefore, we studied in vitro rooting of hypocotyl cuttings of Fraser fir-specifically, the influence of IBA on adventitious rooting.

Seeds were collected in 1981 from native

Received for publication 5 Feb. 1990. Paper no. 12545 of the Journal Series of the North Carolina Agricultural Research Service (NCARS), Raleigh, NC, 27695-7643. From a thesis submitted by C.H.S. in partial fulfillment of the requirements for the $\mathrm{PhD}$ degree. Use of trade names in this publication does not imply endorsement by the NCARS of products named nor criticism of similar ones not mentioned. The North Carolina Forest Service provided seed. The cost of publishing this paper was defrayed in part by the payment of page charges. Under postal regulations, this paper therefore must be hereby marked advertisement solely to indicate this fact.

'Graduate Research Assistant.

${ }^{2}$ Professor.

${ }^{3}$ Associate Professor, Dept. of Forestry. trees growing on that portion of Roan Mountain located in North Carolina (lat. $36^{\circ} 01$ ' $\mathrm{N}$, long. $82^{\circ} 05^{\prime} \mathrm{W}$, elevation $\left.=1900 \mathrm{~m}\right)$, dried to a moisture content of $4 \%$ to $6 \%$, and stored in a polyethylene bag at $-17 \mathrm{C}$. Following removal from storage in 1987 , seeds were immersed in $70 \%$ ethanol for $30 \mathrm{sec}$ to remove surface resin, nicked at the micropylar end with a scalpel and germinated in $1 \%(\mathrm{v} /$ v) $\mathrm{H}_{2} \mathrm{O}_{2}$ for the first 3 days and $0.03 \%(\mathrm{v} / \mathrm{v})$ $\mathrm{H}_{2} \mathrm{O}_{2}$ for an additional 4 days. Hydrogen peroxide solutions were changed each day. Following day 4 of germination, seeds were sterilized daily with either $6 \%(\mathrm{v} / \mathrm{v}) \mathrm{H}_{2} \mathrm{O}_{2}$ for $5 \mathrm{~min}$ or $70 \%(\mathrm{v} / \mathrm{v})$ ethanol for $30 \mathrm{sec}$. These treatments were alternated daily and were used in addition to $\mathrm{H}_{2} \mathrm{O}_{2}$ germination. Seeds were germinated at an 8/16-hr thermoperiod of 30/ 20C and were subjected daily to irradiation from a combination of cool-white fluorescent and incandescent lamps during the 8-hr cycle. The lamps provided a photosynthetic photon flux (PPF) (400-700 nm) of 17.9 $\mu \mathrm{mol} \cdot \mathrm{s}^{-1} \cdot \mathrm{m}^{-2}$. This and all other light measurements were recorded with a LI-COR LI 185A quantum/radiometer/photometer (LICOR, Lincoln, Neb.).

Following $\mathrm{H}_{2} \mathrm{O}_{2}$ germination, germinating seeds were surface-sterilized with $70 \%(\mathrm{v} / \mathrm{v})$ ethanol for $2 \mathrm{~min}$ and $0.5 \%(\mathrm{w} / \mathrm{v}) \mathrm{Ca}(\mathrm{OCl})_{2}$ for $10 \mathrm{~min}$. Embryos were excised and placed vertically in $100 \times 25-\mathrm{mm}$ plastic petri dishes containing $25 \mathrm{ml}$ of a Gresshoff and Doy (GD) medium (pH 5.5), as modified by Mott and Amerson (1981), containing 3\% sucrose and $0.8 \%$ agar. Cultures were transferred to fresh GD medium after 4 weeks. Cultures were maintained at $22 \mathrm{C}$ under continuous irradiation provided by a combination of coolwhite fluorescent and incandescent lamps $\left(\mathrm{PPF}=47 \mu \mathrm{mol} \cdot \mathrm{s}^{-1} \cdot \mathrm{m}^{-2}\right)$.

After 7 weeks on GD medium, radicles were excised, resulting in hypocotyl cuttings. Each cutting consisted of $1 \mathrm{~cm}$ of hypocotyl, the cotyledons, several young needles, and the apical meristem. Cuttings were placed vertically in $60 \times 20$-mm plastic petri dishes containing $10 \mathrm{ml}$ of a modified, half-strength GD medium containing $1 \%$ sucrose, $0.8 \%$ agar, and supplemented with the following concentrations of IBA: 0,5 ,
10, 20, and $40 \mathrm{mg} \cdot \mathrm{liter}^{-1}$. The $\mathrm{pH}$ of the medium was adjusted to 5.5 before autoclaving. The experimental design was a randomized complete block with 15 replications. Within a replication, each treatment consisted of a petri dish containing three cuttings. After 18 days on IBA-containing medium, cuttings were transferred to the same medium without IBA. Thereafter, cuttings were transferred to fresh medium after 4 weeks. During rooting, cultures were maintained at $22 \mathrm{C}$ under a 12 -hr photoperiod provided by a combination of cool-white fluorescent and incandescent lamps (PPF = $37 \mu \mathrm{mol} \cdot \mathrm{s}^{-1} \cdot \mathrm{m}^{-2}$ ).

Data were recorded 11 weeks after cuttings were initially placed on IBA-containing medium. Data included the number of primary roots $>1 \mathrm{~mm}$ in length. Any cutting having one or more roots was- classified as rooted. Means were calculated by petri dish, and data were subjected to analysis of variance and regression analysis.

The bases of cuttings placed on medium containing IBA became swollen by day 18 . The epidermis split on the lower portion of the hypocotyl and white callus protruded. Nontreated cuttings did not swell at the base or produce a friable, white callus. On day 18 , cuttings were transferred to medium lacking auxin. After an additional 4 weeks in culture, roots were visible, and root numbers continued to increase thereafter.

IBA concentration affected both percent rooting and root number. Rooting was greatest $(66 \%)$ following treatment with IBA at $20 \mathrm{mg} \cdot$ liter $^{-1}$ and declined slightly for 40
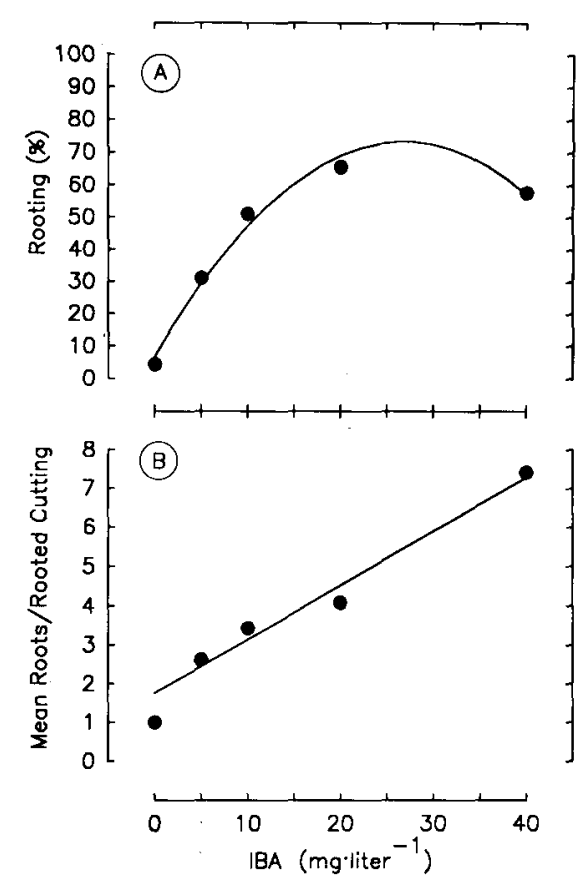

Fig. 1. Influence of IBA on in vitro rooting of hypocotyl cuttings of Fraser fir. (A) Percent rooting; regression model: $\mathrm{Y}=6.96+4.96 \mathrm{X}$ - 0.09X $\mathrm{X}^{2}, R^{2}=0,46, P<0.01$. Each data point is based on 45 observsations. (B) Mean number of roots per rooted hypocotyl cutting; regression model: $\mathrm{Y}=1.77+0.14 \mathrm{X}, R^{2}=$ $0.33, P<0.01$. 
mg.liter ${ }^{-1}\left(58^{\prime} \%\right)$ (Fig. 1A). The regression analysis (Fig. 1A) predicted $26 \mathrm{mg}$ IBA/liter for optimal rooting. Root number increased linearly, and the number of roots per rooted cutting was highest after treatment with 40 mg IBA/liter (Fig. 1B).

For cuttings initially placed on medium containing IBA at $40 \mathrm{mg} \cdot$ liter $^{-1}$ percent rooting declined slightly relative to those exposed to $20 \mathrm{mg} \cdot$ liter $^{-1}$, whereas the number of roots per rooted cutting continued to increase (Fig. 1). At suboptimal IBA concentrations $\left(<20 \mathrm{mg} \cdot\right.$ liter $\left.^{-1}\right)$, both percent rooting and root number decreased (Fig. $1 \mathrm{~A}$ and B). Rooting of nontreated cuttings was negligible (5\%), indicating the importance of auxin in stimulating rooting.

Although satisfactory rooting $(66 \%)$ was attained, higher rooting may be accomplished by examination of environmental factors influencing rooting. Also, use of other auxins, either alone or in combination with IBA, may increase rooting.

Results presented demonstrate the necessity of auxin for promoting in vitro rooting of Fraser fir. Since hypocotyl cuttings of Fraser fir root easily, use of such cuttings may further understanding of adventitious rooting in vitro and help reduce the difficulty of tissue culture propagation. In addition, procedures reported herein may serve as a model system for studying acclimation of plantlets.

\section{Literature Cited}

Amerson, H. V., L.J. Frampton, Jr., S.E. McKeand, R.L. Mott, and R.J. Weir. 1985. Loblolly pine tissue culture: Laboratory, greenhouse, and field studies, p. 271-288. In: R.R. Henke, K.W. Hughs, M.J. Constantin, and A. Hollaender (eds.). Tissue culture in forestry and agriculture. Plenum Press, New York.
Amerson, H. V., L.J. Frampton, Jr., R.L. Mott, and P.C. Spainc. 1988. Tissue culture of conifers using loblolly pine as a model, p. 117137. [n: J. Hanover and D. Keathley (eds.). Genetic manipulation of woody plants. Plenom Press, New York.

Gronroos, R. and S. von Arnold. 1985. Initiation and development of wound tissue and roots on hypocotyl cuttings of Pinus sylvestris in vitro. Physiol. Plant. 64:393-401.

Gronroos, R. and S. von Arnold. 1987. Initiation of roots on hypocotyl cuttings of Pinus contorta in vitro. Physiol. Plant. 69:227-236.

Mott, R.L. and H.V. Amerson. 1981. A tissue culture process for the clonal production of loblolly pine plantlets. North Carolina Agr. Res. Ser. Tech. Bul. 271

Saravitz, C. H., F.A. Blazich, and "H.V. Amerson. 1987. in vitro propagation of Fraser fir (Abies fraseri). HortScience 22:1068. (Abstr.)

Zygmont, N. and O.J. Schwarz. 1987. In vitro adventitious bud formation on cultured embryos of Abies fraseri. In Vitro 23:49A. (Abstr.) 